\title{
SINIRAŞIRI ALACAKLARIN VE BANKA HESABININ HACZIं
}

\author{
The Cross-Border Garnishment of Claims and Bankaccounts
}

Dr. Götz-Sebastian HÖK*

Çeviren: C. Gökhan ERBAŞ LL.M. Köln

1. Mevcut Durum, a) Yetki ve Tanıma, b) Hâkimiyet Alanı Esası, c) Tebligat Problemleri, 2. Yabanc1 Ülke Unsuru, 3. Uluslararası Yetki, 4. Haczin Hukuki Etkileri, a) Hukuki Etkileri, b) Fiili Sonuçlar, c) Nihai Çıkarımlar, 5. Yabancı Ülkedeki Etkileri, 6. Alacakların Bulunduğu Yer, 7. Bağlanma Noktası Olarak Borçlu (Cebri İcra Borçlusu), 8. Aynı Alacağın Tekrar Talep Edilmesi İtirazı, 9. Sonuç

\section{ÖZET}

Sınıraşırı alacakların haczi öteden beridir mevcut olan ve Çekişmesiz Alacaklar Hakkında Avrupa İcra Illâmının Çıkartılmasına Dair 21 Nisan 2004 tarih ve 805/2004/AT sayll Avrupa Parlementosu ve Konseyi Tüzüğ̈̈ nün yürürlüğe girmesiyle önemi gittikçe artan bir problem teşkil etmektedir. Burada zorunlu olarak, 1) icra alacaklısı 2) icra borçlusu ve 3) üçüncü kişi durumundaki borçlu olmak üzere en az üç kişinin katıldığı icra takibinin özel bir çeşidi söz konusudur. Yabancı ülke unsuru ise ya yukarıda

\footnotetext{
$\square$ Bu çalışmada mümkün oldukça Dr. Götz-Sebastian Hök tarafindan kaleme alınan asıl metne bağlı kalınmaya gayret edilmiştir. Şunu da belirtmek gerekir ki, bazı noktalarda az da olsa çeviren tarafından açıklayıcı nitelikte eklemeler yapılmıştır. Asıl metin 2005 yılında Almanya' da Monatsschrift für Deutsches Recht (MDR) isimli derginin 6. sayısında yayımlanmışırı.

$\square{ }^{*}$ Humboldt Üniversitesi eski öğretim üyesi, Eurojuris International Litigation and Safer Export Komisyonu Başkanı.
} 
sayılan taraflardan birisinin icra takibinin yapıldığ 1 ülke içerisinde mukim olmaması ya da alacağın yabancı ülkede bulunması halinde ortaya çıkmaktadır. Yabancı ülke unsuru ayrıca hacze konu olan alacağa uygulanacak hukuktan ve bundan dolayı muhtemelen ortaya çıkabilecek bir yabancı ülke mahkemesinin yetkisinden de kaynaklanabilmektedir. Haciz yetkisinin söz konusu olabilmesi için hangi ölçüde veya ne kadar az yurtiçi unsurunun olması gerektiği ya da olmasına müsaade edildiği, karşılaştırmalı hukuk kapsamında değerlendirilmiştir.

Anahtar Kelimeler: Sınıraşırı, alacak, banka hesabı, 805/2004, haciz

\section{ABSTRACT}

The cross-border garnishment of claims has always been a problem, which will gain more importance after the enactment of EC Regulation No 805/2004 of the European Parliament and of the Council of 21 April 2004 creating a European Enforcement Order for uncontested claims. It is a special form of enforcement in which at least three persons are involved: (1) the creditor (2) the debtor (3) and the third-party debtor. There is a foreign element when one of the three parties isn't a resident of the country where enforcement is sought or when the claim to be attached itself is located in a foreign country. The foreign element results further from the applicable law of the attached claim and probably existing international venue in connection with attached claim. To which extent foreign elements may or must exist in order to obtain a garnishment order (third party-debt order) is the subject of this comparative law research.

Keywords: Cross-border, claim, bank account, 805/2004, garnishment

Sınıraşırı alacakların haczi, öteden beridir mevcut olan ve Çekişmesiz Alacaklar Hakkında Avrupa İcra Illâmının Çıkartılmasına Dair 21 Nisan 2004 tarih ve 805/2004/AT sayll Avrupa Parlementosu ve Konseyi Tüzüğ̈̈ (EuVTVO) 'nün ${ }^{1}$ yürürlüğe girmesiyle önemi gittikçe artan bir problem teşkil etmektedir. Burada söz konusu olan, 1) cebri icra alacaklıs1 2) cebri icra borçlusu ve 3) üçüncü kişi olmak üzere zorunlu olarak en az üç kişinin katıldığı icra takibinin özel bir türüdür. Yabancı ülke unsuru ise ya yukarıda sayılan taraflardan birisinin icra takibinin yapıldığ 1 ülke içerisinde mukim olmaması ya da alacağın yabancı ülkede bulunması halinde ortaya

1 ABl 2004 Nr. L 243, 15 vd.; krş. Hess IPRax 2004, 493; Jayme/Kohler IPRax 2004, 481 vd.; Verordnung (EG) Nr. 805/2004 des Europäischen Parlaments und des Rates vom 21. April 2004 zur Einführung eines europäischen Vollstreckungstitels für unbestrittene Forderungen (Regulation (EC) No 805/2004 of the European Parliament and of the Council of 21 April 2004 creating a European Enforcement Order for uncontested claims). 
çıkmaktadır. Yabancı ülke unsuru ayrıca, hacze konu olan alacağa uygulanacak hukuktan ve bu hususta muhtemel olarak ortaya çıkabilecek bir yabancı ülke mahkemesinin yetkisinden de kaynaklanabilmektedir. Haciz yetkisinin söz konusu olabilmesi için yurtiçi unsurunun hangi ölçüde olması gerektiği ya da veya ne kadar az olmasına müsaade edildiği karşılaştırmalı hukuk kapsamında farklı farklı değerlendirilmektedir. ${ }^{2}$

\section{Mevcut Durum}

Kendi hâkimiyet alanı içerisinde yer alan eşyalara el koyma yetkisinin sadece ilgili ülkeye aidiyeti hususu, bir ülkenin egemenliğinin gereğidir. ${ }^{3} \mathrm{Bu}$ ulusal egemenlik, sınırlarını diğer ülkelerin benzer egemenlik haklarıyla karşılaştığı noktada bulmaktadır. ${ }^{4}$ Cebri icra ile alâkalı olarak bu devletler hukuku esası açık bir şekilde EuGVVO ${ }^{5}$ md. 22 nr. 5 (EuGVÜ ${ }^{6}$ md. 16 nr. 5) içerisinde ifadesini bulmaktadır. ${ }^{7}$ Yabancı bir ülkenin banka hesabı şeklindeki malvarlığı, mülkî amaçlara hizmet ettiği sürece, Alman icra yetkisi kapsamı dışındadır. ${ }^{8}$

2 USA: Harris v. Balk 198 U.S. 215; Shaffer v. Heitner 433 U.S. 186; Feder v. Turkish Airlines 441 F.Supp. 1273 (S.D.N.Y. 1977); Carolina Power \& Light Co. v. Uranex 451 F.Supp. 1044 (N.D.Cal. 1977); Fransa: Cass.civ., 30.01.2002, JCP (E) 2003, 663, 664; TGI Paris, 28.09.1998, Gaz. Pal. 1998, 37; TGI Nîmes, 09.06.1998, D. 1999, 301 Cuniberti'nin aksi yöndeki şerhi ile; İngiltere: Martin v. Nadel [1906] 2 K.B. 26; krş. Rheinstein RabelsZ 8 (1934), 277, 299; SCF Finance Co. Ltd. v. Masri (No 3) [1987] Q.B. 1028; Kuwait Oil Tanker Company SAK and others v. UBS AG [2003] UKHL 31, http://www.publications.parliament.uk/pa/ld200203/ldjudgmt/jd030612/kuwa-1.htm; İsviçre: BGE 107 III, 147 vd.; Almanya: LG Berlin I KG Bl 1927, 128; RG IPRspr. 3 (1928) Nr. 134; RGZ 132, 128, 130; LG Bonn MDR 1955, 617; OLG Saarbrücken IPRax 2001, 456; KG NJOZ 2001, 727; OLG Köln IPRax 2004, 251, 253; BAG IPRax 1997, 335; aksi görüş için bak.: Schack IPRax 1997, 318 vd.; krş. EuGH vom 21.05.1980, Rs 125/79, IPRax 1981, 95.

3 OLG Saarbrücken IPRax 2001, 456; Jestaedt IPRax 2001, 438, 440; Schmidt MDR 1956, 204.

4 krş. Mann, Further Studies in International Law, 4.

5 Verordnung (EG) Nr. 44/2001 des Rates vom 22. Dezember 2000 über die gerichtliche Zuständigkeit und die Anerkennung und Vollstreckung von Entscheidungen in Zivil- und Handelssachen (Özel Hukuk ve Ticaret Hukuku Konularında Yargı Yetkisi, Yargı Kararlarının Taninması ve Tenfizine Dair 22 Aralı 2000 tarih ve 44/2001/AT sayll Konsey Tüzüğ̈ - Council Regulation (EC) No 44/2001 of 22 December 2000 on jurisdiction and the recognition and enforcement of judgments in civil and commercial matters).

6 Übereinkommen von Brüssel über die gerichtliche Zuständigkeit und die Vollstreckung gerichtlicher Entscheidungen in Zivil- und Handelssachen vom 27 September 1968 (Özel Hukuk ve Ticaret Hukuku Konularında Yargı Yetkisi ve Yargı Kararlarının Tenfizine Dair 27 Eylül 1968 tarihli Brüksel Anlaşmast -1968 Brussels Convention on jurisdiction and the enforcement of judgments in civil and commercial matters).

7 krş. Geimer/Schütze, Europäisches Zivilverfahrensrecht, md. 22 prg. 1, 4, 264.

8 OLG Köln IPRax 2004, 251, 253; krş. OLG Frankfurt NJW 1981, 2650; krş. BGH NJWRR 2003, 1218; krş. Both/Hök, Praxis der Zwangsvollstreckung, Kıısım 11 prg. 258. 


\section{a) Yetki ve Tanıma}

Şu ana kadar, uluslararası icra yetkisi hakkında milletlerarası sözleşme niteliğinde bir düzenleme mevcut değildir. ${ }^{9} \mathrm{Bu}$ tür kurallar her defasında yerel yetki hakkındaki ulusal hükümlerden hareketle türetilmektedir. ${ }^{10}$ Son zamanlarda bir fikir değişikliğine gidilerek, İngiltere'de EuGVVO md. 22 nr. 5 (EuGVÜ md. 16 nr. 5)'den münhasır uluslararası icra yetkisi kuralı çıkarılmıştır. ${ }^{11}$ Diğer taraftan esas itibariyle icra organlarının, kendi kararlarının yurtdışında da etki gösterip göstermeyeceği konusunda bir kaygı taşımaları gerekmemektedir. ${ }^{12} \mathrm{Bu}$ kararların yabancı ülkede tanınması lex fori (hâkimin hukuku) kapsamındaki devletler özel hukuku kuralları da dahil olmak üzere sadece ilgili lex fori (hâkimin hukuku) kuralları uyarınca gerçekleşecektir. ${ }^{13}$ Nihayetinde belirli sınırlar içerisinde yabancı icra kararları ve dolayısıyla bunların hukuki sonuçları (örneğin, eşyalar üzerindeki haciz rehin hakkı) tanınacaktır. ${ }^{14}$

\section{b) Hâkimiyet Alanı Esası}

Hâkimiyet alanı esası, dünya çapında yabancı ülkelerin yargı yetkisi alanına müdahale içeren icra işlemlerini yasaklamaktadır. ${ }^{15}$ Temel itibariyle bu noktada şu düşünceler ön plana çıkmaktadır:

Hâkimiyet alanı esası ulusal hâkimiyet erkinin kullanılmasını sınırlamaktadır ve böylece yetki mülahazaları içerisinde (örneğin EuGVVO md. 22 nr. 5 açısından) yerini alabilmelidir. ${ }^{16}$ Diğer bir devletin hâkimiyet alanına müdahalenin söz konusu olması halinde yurtiçi icra işlemleri imkânsızlaşmaktadır. ${ }^{17}$ Ülke içerisindeki mahkemelerin ilgili konu hakkında yetkili olmamaları halinde tereddüde mahal verecek durumlar ortaya çıkmamaktadır. Buna karşın, örneğin hâkimiyet alanı esasının çok dar olarak kullanılmış olması halinde hukuki koruma alanı boşlukları oluşabilmektedir.

9 krş. Geimer/Schütze, Europäisches Zivilverfahrensrecht, md. 22 prg. 262 vd.

${ }^{10} \mathrm{krş.} \mathrm{Nagel/Gottwald,} \mathrm{IZPR,} \mathrm{§} 17$ prg. 27, 57; Stein/Jonas/Brehm, ZPO, § 828 prg. 7; Both/ Hök, Praxis der Zwangsvollstreckung, Kısım 11 prg. 275.

11 krş. Kuwait Oil Tanker Company SAK and others v. UBS AG [2003] UKHL 31, http://www.publications.parliament.uk/pa/ld200203/ldjudgmt/jd030612/kuwa-1.htm.

12 krş. OLG Saarbrücken IPRax 2001, 456; OLG Breslau Seuff. Arch. 50 Nr. 65.

$13 \mathrm{Krş.} \mathrm{Stein/Jonas/Brehm,} \mathrm{ZPO,} \mathrm{§} 829$ prg. 105.

$14 \mathrm{Nagel} /$ Gottwald, IZPR, § 17 prg. 29; Stein/Jonas/Brehm, ZPO, § 829 prg. 105.

15 Nagel/Gottwald, IZPR, $§ 17$ prg. 3; Dalloz Action, Droit et Pratique des voies d'exécution, prg. 9945; krş. LG Berlin I KG Bl 1927, 128; Société Eram Shipping Company Ltd. v. Hong Kong and Shanghai Banking Corp. Ltd. [2003] UKHL 30, http://www.publications.parliament.uk/pa/ld200203/ldjudgmt/jd030612/soci-1.htm.

16 krş. Born/Fallon/Boxstael, Droit judiciaire international, prg. 231; Reichel AcP 1929, 293, 297.

17 krş. TGI Nîmes D. 1999, 301 Cuniberti nin şerhi ile. 
Aynı alacağın ikinci defa talep edilme riski itirazını kabule yönelik olarak hâkimiyet alanı esasını maddi icra hukukunun bir parçası olarak kabul etmek $^{18}$ de düşünülebilir. $\mathrm{Bu}$ durum somut olayda hakkaniyet mülahazaları için karar vermeye yönelik büyük bir hareket alanı sağlayacaktır, buna karşın duruma göre ortaya çıkabilecek olan yüksek açılama/ispat taleplerinin aşılması gereklidir. Bu noktada hukuk güvenliği, özellikle icra işleminin içerisinde bu tür düşüncelerin sisteme aykırılık teşkil edebileceği bir mahiyette şekillendirilmiş bir süreç olması halinde zarar görmektedir.

Son olarak, çatışan kararlar alanında olduğu gibi, bu esasın sadece ulusal işlemlere yönelik etki kısıtlamasının bir parçası olarak anlaşılması gerektiğ $i^{19}$ akla gelmektedir. Avrupa Adalet Divanı [Europäischer

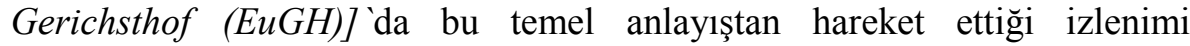
vermektedir. ${ }^{20}$

\section{c) Tebligat Problemleri}

Tebligatın bu şekliyle egemenlik hakkına dayanan bir işlem olarak algılanması nedeniyle, ulusal makamlar tarafından yurtdışına tebligat yapılamaması gerekmektedir. ${ }^{21}$ Pek tabii bu anlayış kabul görmemiştir. ${ }^{22}$ Bunun yanında yabancı bir ülkeye yapılacak tebligatlar için ya hukuki yardım (istinabe) sürecinin başlatılması ya da devletler hukuku alanında bir dayanağın mevcut olması gerekmektedir. Buna karşın $\mathrm{AB}$ ülkeleri haricinde yabancı ülke makamlarının yardımları her zaman sağlanamamaktadır. ${ }^{23} \mathrm{AB}$ içerisinde tebligat, 1348/2000 sayılı Konsey Tüzüğü ${ }^{24}$ ile düzenlenmiştir. ${ }^{25}$ Alacaklının icra takibi başlatmasıyla birlikte tebligat gerçekleştirilir, ki bunun için henüz başvuru esnasında bile Alman asliye mahkemesinden [Amtsgericht $(A G)]$ talepte bulunulabilecektir. ${ }^{26}$ 1.7.2002 tarihinden itibaren

18 krş. Martin v. Nadel [1906] 2 K.B. 26; Swiss Bank Corp. v. Böhmische Industrial Bank [1923] 1 K.B. 673; SCF Finance Co. Ltd. v. Masri (No. 3) [1987] Q.B. 1028.

19 krş. OLG Breslau JW 1885, 261, 263; Kaufmann JW 1929, 416, 417; Stein/Jonas/Brehm, ZPO, § 829 prg. 105.

${ }^{20}$ krş. EuGH IPRax 1981, 95; EuGH, Urt. v. 17.11.1998, Rs. C 391/95 prg. 47.

${ }^{21}$ KG JW 1929, 2360.

22 RGZ 22, 404; OLG Breslau Seuff. Arch. 50 Nr. 65; LG Berlin I KG Bl 1927, 128.

23 krş. Schack Rpfleger 1980, 175, 176; Schuschke/Walker, Vollstreckung und Vorläufiger Rechtsschutz, vor $\S \S 828-863$ prg. 2.

24 Verordnung (EG) Nr. 1348/2000 des Rates vom 29. Mai 2000 über die Zustellung gerichtlicher und außergerichtlicher Schriftstücke in Zivil- oder Handelssachen in den Mitgliedstaaten (Üye Devletler İçerisinde Özel Hukuk ve Ticaret Hukuku Konularında Adli ve Adli Olmayan Belgelerin Tebliğine Dair 29 Mayls 2000 tarih ve 1348/2000/AT sayll Konsey Tüzüğ̈̈ - Council regulation (EC) No 1348/2000 of 29 May 2000 on the service in the Member States of judicial and extrajudicial documents in civil or commercial matters).

${ }^{25}$ AB1 Nr. L 160 vom 30.06.2000, 37 vd., üçüncü kişiye tebligat hakkında Schuschke/Walter, Vollstreckung und Vorläufiger Rechtsschutz, vor $\S \S 828-863$ prg. 2.

${ }^{26}$ Both/Hanebrink, Praxis der Zwangsvollstreckung, K1sim 2 prg. 53. 
bu konuda icra memuru yetkilidir. Eskiden üçüncü kişiye yönelik olarak ilanen tebligat yapılamamaktaydı, ${ }^{27}$ 1.7.2002 tarihinden itibaren üçüncü kişi durumdaki borçluya genel itibariyle ilanen tebligat yapılabilmektedir. ${ }^{28}$ Hatta bunun için gerekli olan şartların kural olarak oluşamamış olmasına rağmen ilanen tebligat gerçekleştirilebilmektedir. ${ }^{29}$ Uygulamada üçüncü kişiye yapılan ödeme yasağını içeren tebligatın, üçüncü kişiye yönelik bir icra takibi niteliğinde olmadığ 1 kabul edilmiştir. ${ }^{30}$ İcra takibi yapılan ülkenin ya da üçüncü kişinin ikamet ettiği ülkenin üçüncü kişiye tebligat yapmayı reddetmesi halinde alacaklı icra ilamını üçüncü kişinin ikamet ettiği ülkede tanınmasını sağlamalı ve orada haczi tekrarlamalıdır. ${ }^{31}$

\section{Yabancı Ülke Unsuru}

Özellikle banka hesaplarının haczi problem teşkil etmektedir. Tüm büyük yerli ve yabancı bankalar, birden çok ülkede faaliyet göstermektedirler ve dünya üzerindeki farklı yerlerde hesap işlemleri yapan şubelere sahiptirler. ${ }^{32}$ Bir alacaklının, uluslararası faaliyet gösteren bir bankanın yurtdışındaki farklı şubelerinde hesabı olan bir borçluya karşı icra takibi başlatması halinde, yabancı ülke unsurunun oluşup oluşmadığı sorusu karşımıza çıkmaktadır.

Durum karşılaştırmalı hukuk açısından değerlendirildiğinde, yabancı ülke ilişkisinin hukuki olarak tanımlanabileceği kanısı şimdiye kadar hâkim olmuştur. $\mathrm{Bu}$ konuda ağırlıklı olarak alacağın bulunduğu yer esasına dayanılmaktadır. ${ }^{33} \mathrm{Bu}$ noktada karşılaştırmalı hukuk açısından belirtmek gerekir ki bu esas farklı farklı değerlendirilmektedir ve ayrıca haciz dava konusunun yurtiçinde olmaması halinde dahi geçerli olmalıdır. ${ }^{34}$ Pek çok

${ }^{27}$ Schack Rpfleger 1980, 175, 176.

28 Schuschke/Walker, Vollstreckung und Vorläufiger Rechtsschutz, § 829 prg. 43; Zöller/Stöber, ZPO, § 829 prg. 14; farklı görüşte: Musielak/Becker, ZPO, § 829 prg. 14; Both/Hanebrink, Praxis der Zwangsvollstreckung, Kısım 2 prg. 53.

29 Ek olarak: Schuschke/Walker, Vollstreckung und Vorläufiger Rechtsschutz, § 829 prg. 43.

30 krş. Keil JW 1929, 2360.

31 krş. Kropholler, Europäisches Zivilprozessrecht, § 38 prg. 5; Schuschke/Walker, Vollstreckung und Vorläufiger Rechtsschutz, vor $\S \S 828$ - 863 prg. 2.

32 Krş. Mühlhausen WM 1986, 957 vd., 985 vd.

33 Krş. BGHZ 7, 302, 304; RGZ 36, 355, 357; LG Berlin I KG Bl 1927, 128; BGE 107 III, 147.

${ }^{34} \mathrm{Krş.} \mathrm{Stein/Jonas/Brehm,} \mathrm{ZPO,} \mathrm{§} 829$ prg. 24. 
ülke alacağın yeri olarak üçüncü kişinin ikametgâhını kabul etmekte, ${ }^{35}$ İsviçre ise borçlunun ikametgâhını kabul etmektedir. ${ }^{36}$

Fakat hiç bir kombinasyonu gözden kaçırmamak için yabancı ülke unsuru kavramı gerçekten anlaşılmalı ve yabancı ülke unsurunun mevcut her bir türü üzerinde düşünülmelidir. Böylece yanıltıcı durumlar ve yanılgıya sürükleyici kazuistik önlenmiş olacaktır. Sonuç olarak üç taraftan birisinin yurtdışında ikâmet etmesi ya da üçüncü kişinin şubelerinin yurtdışında faaliyet göstermesi halinde yabancı ülke unsuru mevcuttur.

\section{Uluslararası Yetki}

Alacakların haczi konusunda uluslararası yetki Almanya'da açı bir şekilde ZPO [Zivilprozessordnung (Alman Hukuk Usulü Muhakemeleri Kanunu)] md. 828 f. 2 hükmünden ${ }^{37}$ çıkmaktadır ve her halükârda borçlunun ikametgâhındaki, üçüncü kişinin ikametgâhındaki ve teminatın ${ }^{38}$ bulunduğu yerdeki mahkemenin yargı yetkisi mevcuttur. Burada bahsi geçen teminat haczedilecek alacak için verilen teminattır. ${ }^{39}$ İngiltere'de son zamanlarda, üçüncü kişinin kendisinden talep edilen alacakla ilgili olarak İngiliz yargısına tâbi olması halinde uluslararası yetkinin CPR [Civil Procedure Rules (Íngiliz Hukuk Usulü Muhakemeleri Kanunu)] Part. 72.1 (1) hükmünden çıkarıldığı kabul edilmektedir. Fransız icra organları, Fransa' da bulunan malvarlıkları ile ilgili tüm icra işlemleri için yetkilidir. ${ }^{40}$ Haczedilecek alacağın yabancı bir ülke hukukuna tâbi olması ve yabancı bir ülkedeki bir mahkemenin yetkisi konusunda anlaşılmış olması konuları Fransız anlayışına göre dikkate alınmamaktadır. ${ }^{41}$ Eski yargı kararlarına göre üçüncü kişinin ikametgâhı yabancı bir ülkede de olabilmekteydi. ${ }^{42}$ ABD'de öncelikle jurisdiction in rem in (eşyalara göre belirlenen yargl yetkisinin)

35 Almanya: unter Bezugnahme auf $\S 23$ ZPO RGZ 36, 355, 357; RGZ 77, 250, 252; RGZ 140, 340, 343; RG Seuff. Arch. 63 Nr. 27; Fransa: Dalloz Action, Droit et Pratique des voies d'exécution, prg. 9951; Perrot/Théry, Procédures civiles d'exécution, prg. 33; Cuniberti JCP (E) 2003, 664, 665; Loussouarn/Bourel, Droit international privé, prg. 448 ; Mayer/Heuzé, Droit international privé, prg. 287; Cass.civ., 30.01.2002, JCP (E) 2003, 663; İngiltere : Société Eram Shipping Company Ltd. v. Hong Kong and Shanghai Banking Corp. Ltd. [2003] UKHL 30: a debt is [generally] situate in the country where the debtor resides, http://www.publications.parliament.uk/pa/ld200203/ldjudgmt/jd030612/soci-1.htm; Swiss Bank Corp. v. Böhmische Industrial Bank [1923] 1 K.B. 673: „If the debt is situate, or in other words if it is properly recoverable, in this country"; USA: Scoles/Hay, Conflict of Laws, § 7.3; Österreich: JN md. 99 f. 2.

36 BGE 47 III, 75; BGE 53 III, 45, BGE 107 III 147, 149.

37 OLG Köln IPRax 2004, 251, 253; OLG Saarbrücken IPRax 2001, 456; krş. Schuschke/Schuschke, Vollstreckung und Vorläufiger Rechtsschutz, § 828 prg. 5; Geimer, IZPR, prg. 1224; Musielak/Becker, $§ 828$ prg. 3; Mössle, Internationale Forderungspfändung, 93.

38 krş. Mössle, Internationale Forderungspfändung, 107.

39 LG Berlin I KG B1 1927, 128.

40 krş. Versailles, 13.05.1986, D. 1987, somm. 348.

41 Cass.civ., 06.12.1989, Rev.crit. 1990, 545. 
mevcut olup olmadığı araştırılmalıdır, ki bu durum yetki açısından göz önünde bulundurulmalıdır. ${ }^{43}$

Egemenlik konusundaki tereddütler yetki kuralları içerisinde yeterince açık bir şekilde ifadesini bulmamaktadır. Ayrıca yetkililik ve icra erki ayrı ayrı değerlendirilmelidir. ${ }^{44}$ Ama haczedilecek alacağın yurtiçinde bulunuyor olması Alman anlayışı uyarınca hiç bir şekilde yurt içinde gerçekleştirilecek bir icra takibini gerektirmemektedir. ${ }^{45}$

\section{Haczin Hukuki Etkileri}

Haczedilen alacağın durumu, haczin gerçekleștirilebilirliği, alacağın haczedilebilirliği ve haczin hangi şarlarda kalkacağı ilgili asıl alacağın tâbi olduğu hukuka göre belirlenir. ${ }^{46}$ Yabanc1 bir ülke hukukunun uygulanabilirliği yurtiçindeki haczin gerçekleştirilmesini engellemez. ${ }^{47}$ Buna karşın haczin etkisi ya icra takibi yapılan ülke hukukuna, yani icra takibi yapan mahkeme ${ }^{48}$ esas alınarak lex fori (hâkimin hukuku) kurallarına, ya da ilgili hukuk süjesinin hukuki durumu dikkate alınarak lex rei sitae ${ }^{49}$ (dava konusu eşyanın bulunduğu yer hukuku) kurallarına göre belirlenir. Hangi çözüm metodunun uygulanması gerektiğini netleştirmek amacıyla, alacağın haczinin hangi etkileri göstereceği açıklığa kavuşturulmalıdır. Bu noktada hukuki ve fiili sonuçlar birbirinden ayırt edilmelidir.

\section{a) Hukuki Etkileri}

Hukuki açıdan bakıldığında, bir alacağın haczi üçüncü kişinin artık borcundan kurtulmak amaciyla borçluya ödeme yapamaması sonucuna götürmektedir. ${ }^{50}$ Böylece haczedilen alacak cebri icra alacaklısına, kendi alacağına yetecek kadar olan kısmını almak üzere tahsis edilir. ${ }^{51}$ Sonrasında

42 Paris, 13.12.1932, Clunet 1934, 1207; Douai, 08.07.1929, Clunet 1930, 1003; krş. Schnitzer, Handbuch des IPR, 890 ve "saisie foraine" kavramının tarihi hakkında: Riezler, Internationales Zivilprozessrecht, 73.

${ }^{43} \mathrm{krş}$. Scoles/Hay, Conflict of laws, $\S 7.3$.

44 OLG Hamburg Niemeyer'sZ 1902, 271, 278; OLG Breslau Seuff. Arch. 50 Nr. 65; OLG Breslau JW 1885, 261, 263; krş. OLG Saarbrücken IPRax 2001, 456; OLG Köln IPRax 2004, 251, 253.

45 farklı görüşte Reichel AcP 1929, 293, 298 vd.

46 krş. Rheinstein RabelsZ 8 (1934), 277, 303; differenzierend Gottwald IPRax 1991, 285, 290; haczedilebilirlik ile ilgili olarak farklı görüşte: Reichel AcP 1929, 293, 303; haczedilebilirlik konusunda aynı şekilde Stein/Jonas/Brehm, ZPO, § 829 prg. 105; Schack IPRax 1997, 329.

${ }^{47}$ RGZ 77, 250, 252; Reichel AcP 1929, 293, 301.

48 RG Seuff. Arch. 63 Nr. 27; Geimer, IZPR, prg. 2794; Reichel AcP 1929, 293, 301.

49 BGH NJW 1989, 1351.

50 İngiltere: Chatterton v. Watney (1881) 17 Ch D 259, 262; Almanya: ZPO md. 829 f. 1 (krş. Oberstes Tribunal zu Kaunas JW 1927, 2349); Fransa: md. 42 v.d. Kanun Nr. 91-650.

${ }^{51}$ İngiltere: Chatterton v. Watney (1881) 17 Ch D 259, 262; Fransa: md. 42 vd. Kanun Nr. 91-650. 
üçüncü kişinin cebri icra alacaklısına yaptığ 1 ödeme, cebri icra borçlusuna karşı borçtan kurtarıcı bir etki gösterir, yani cebri icra borçlusu üçüncü kişiden alacağını artık talep edemez. ${ }^{52}$

Haciz, bu etkileri ilk olarak sadece icra takibi yapılan ülke içerisinde gösterir. ${ }^{53}$ Hâkimiyet alanı esası haczin etkilerini, icra takibi yapılan ülkenin hâkimiyet alanı ile sınırlamaktadır. Buna karşın istisnalar da mevcuttur. Fransa'da oturan üçüncü kişi, cebri icra borçlusu için yurtdışında muhafaza ettiği miktarlar üzerinde bilgi vermek zorundadır. ${ }^{54}$ Bir tüzel kişi ve onun yurtdışındaki şubeleri bir bütünlük arz etmektedir. ${ }^{55}$ Şubenin bulunduğu yabancı bir ülkede başlatılan haciz bu nedenle yurtiçindeki merkezi de kapsamaktadır. ${ }^{56}$ Alman İmparatorluk Mahkemesi [Reichsgericht $(R G)$ ] daima alacakların şubenin bulunduğu yerde değil de borçlunun merkezinin asıl bulunduğu yerde mevcut olduğunu vurgulamıştır. ${ }^{57}$ Fakat yabancı ülke makamlarının, "Almanya daki alacağın talep edilmesini engelleyen" talimatlar vermeleri halinde, Versailler Sözleşmesi 1şı̆̆ı altında, Alman İmparatorluk Mahkemesinin görüşünden etkilenilmemelidir. ${ }^{58}$ Zamansal olarak daha önce başlatılan haciz önceliğe sahiptir. ${ }^{59}$ Üçüncü kişinin (örneğin bankanın) yabancı bir mahkeme kararı nedeniyle cebri icra borçlusuna (hesap sahibine) ödeme yapması, fakat yurtiçindeki haczin devam etmesi halinde problemler ortaya çıkabilmektedir. ${ }^{60}$ Almanya'da, böyle bir problemin varlığı, yurtiçindeki haczin zaman itibariyle öncelikli olması halinde kabul edilmektedir. ${ }^{61}$

\section{b) Fiili Sonuçlar}

Haczedilen alacağın üçüncü kişi tarafından cebri icra alacaklısına ödenmesi suretiyle kapatılması, fiili olarak cebri icra borçlusunun zenginleşmesi sonucuna götürecektir. Eğer ödeme yurtdışında gerçekleştirilen ve yurtiçinde tanınmamış olan bir haciz işlemine dayanıyor

52 İngiltere: Chatterton v. Watney (1881) 17 Ch D 259, 262; Fransa: md. 62 Kararname 92-755.

53 Rheinstein RabelsZ 8 (1934), 277, 287; Schmidt MDR 1956, 204; krş. RGZ 22, 406.

54 Cass.com., 30.05.1985, Rev.crit. 1986, 329 Battifol'un şerhi ile; Cass.civ., 30.01.2002, JCP (E) 2003, 663, 664 Cuniberti'nin şerhi ile.

55 Nagel/Gottwald, IZPR, § 17 prg. 69; Welter, Zwangsvollstreckung und Arrest, 69; Cass.civ., 30.01.2002, JCP (E) 2003, 663, 664; RGZ 107, 44, 45; RGZ 108, 265, 267; RGZ 130, 23, 25; ayrıca krş. LG Frankfurt WM 1987, 239; farklı görüște Mühlhausen WM 1986, 957 vd., ve 985 vd.

56 OLG Hamburg Niemeyer'sZ 1902, 271, 281; krş. Cass.civ., 30.01.2002, JCP (E) 2003, 663, 664; farklı görüşte Cuniberti JCP (E) 2003, 664, 665.

57 RGZ 107, 44, 47; RGZ 108, 265, 267; RGZ 109, 358; RGZ 130, 23, 27.

58 RGZ 107, 44, 48; RGZ 108, 265, 268; RGZ 110, 380, 381; bankanın, hesap sahibinin havale talimatını yerine getirmemesi konusunda krş. RGZ 130, $23 \mathrm{vd}$.

59 OLG Hamburg Niemeyer'sZ 1902, 271; krş. RGZ 36, 355, 357.

60 Ayrıca krş. RGZ 77, 250; BGHZ 7, 302, 306.

${ }^{61}$ RGZ 77, 250, 253. 
ise, cebri icra borçlusu hukuki dayanağın yokluğu nedeniyle sebepsiz zenginleşecektir. Cebri icra borçlusuna rücu şartları ödenen alacağın tâbi olduğu hukuka tâbidir. ${ }^{62}$ Cebri icra borçlusunun, üçüncü kişiden talepte bulunması halinde, bu kişi takas beyanında bulunabilir ya da sebepsiz zenginleşme def' inde bulunabilir. ${ }^{63}$ Bunun şartları ve etkileri aynı şekilde, talep edilmesi üzerine takas beyanında bulunulan alacağın tâbi olduğu hukuka göre belirlenir. ${ }^{64}$ Bununla birlikte İngiliz Lordlar Kamarası böyle bir çözüm konusunda ciddi endişeler taşımaktadır, çünkü öncelikle borçlunun iflasını önlemeye yönelik bir koruma mevcut değildir ve diğer taraftan mahkemenin bulunduğu ülke açısından bakıldığında geçersiz ve tanınması mümkün olmayan yabancı bir icra işleminin yerine getirilmesinin zenginleşme sebebi olarak kabul edilip edilmeyeceği şüphelidir. ${ }^{65}$ Buna karşın üçüncü kişinin hacze rağmen, cebri icra borçlusuna ödemede bulunması halinde ${ }^{66}$ cebri icra alacaklısının alacağ 1 mevcudiyetini devam ettirecektir. İcra takibi alacaklısının kabul edilebilir nitelikteki yer yönünden yetkili bir yarg1 merciinde icra ilamının varlığını ispatlayabildiği durumlarda, üçüncü kişi, cebri icra alacaklısının dava açma riski ile karşı karşıya kalacaktır. Haczin yabancı ülkede çıkartılan ve üçüncü kişinin ülkesinde tanınmayan bir ödeme yasağına dayanması halinde, üçüncü kişinin mahkum edilme tehlikesi (sadece) icra takibinin yapıldığ ülkede ve haczi tanıyan diğer üçüncü bir ülkede mevcuttur. Örneğin bir Alman mahkemesinin Portekiz'de oturan bir borçlunun Almanya'da oturan üçüncü kişiden alacağını, Almanya'da oturan bir alacaklı yararına haczetmesi halinde ve Portekiz' in bu haczi kabul etmemesi halinde Almanya'da oturan üçüncü kişi, (Portekiz'de) meseleye uygun yer yönünden yetkili yargı merciinin mevcut olması halinde alacağın Portekiz'de kendisinden tekrar talep edilmesi riskini taşımaktadır. ${ }^{67}$

\section{c) Nihai Çıkarımlar}

İcra takibinin yurtiçinde ve yurtdışında çok taraflı yargısal bir süreç olduğu ya da yargısal işlem benzeri bir süreç olduğu açıktır. Bu durum yabancı icra takiplerinin etkisi konusunda ilgili icra takibinin yürütüldüğü devletin lex fori (hâkimin hukuku) kurallarının uygulanması gerektiğini göstermektedir. ${ }^{68}$ Diğer taraftan cebri icra takibi hâkimiyet alanı ile sınırlı bir etki göstermektedir ve nihayetinde daima sadece icra takibi yürütülen devletin yargı yetkisine tâbi olan varlıklar ile ilgilidir. Bu durum ise lex rei

${ }^{62}$ Looschelders, IPR, md. 38 prg. 15.

63 Rheinstein RabelsZ 8 (1934), 277, 288.

${ }^{64}$ BGHZ 38, 254, 256; BGH NJW 1994, 1413, 1416.

${ }^{65}$ BGHZ 38, 254, 256; BGH NJW 1994, 1413, 1416.

${ }^{66} \mathrm{Krş.} \mathrm{RGZ} \mathrm{77,} 250$.

${ }^{67} \mathrm{Krş}$. RGZ 77, 250 vd.

${ }^{68}$ RG Seuff. Arch. 63 Nr. 27. 
sitae (dava konusu eşyanın bulunduğu yer hukuku) kurallarının uygulanabilirliğini göstermektedir. Fakat ön planda icra takibi süreci ve icra işlemi bulunmaktadır. $\mathrm{Bu}$ mülki işlem icra takibinin dayanağını oluşturmaktadır ve icra takibi yapılan ülkenin lex fori (hâkimin hukuku) esaslarından hareketle, ortaya çıkacak etkileri somut olarak belirler. $\mathrm{Bu}$ nedenle icra takibi bir usul hukuku işlemi olarak kanunlar ihtilafı hukuku kapsamında tercihen uluslararası yeknesaklık içerisinde icra takibinin yürütüldügü devlet açısından lex fori (hâkimin hukuku) kuralları uyarınca değerlendirilmelidir. Buna karşın, söz konusu işlemin yurtdışında tanınması ilgili yabancı ülkenin lex fori (hâkimin hukuku) kuralları uyarınca değerlendirilmekte iken, yeknesak bir uluslararası icra hukukunun eksikliği nedeniyle sadece icra işleminin etkileri ve sonuçları icra takibinin yürütüldügü ülke içerisinde, icra takibinin yürütüldüğü devletin lex fori (hâkimin hukuku) kuralları uyarınca şekillenmektedir. Ayrıca yurtdışında oturan bir borçlunun bir Alman icra takibi sürecinde hangi ölçüde icrayı sınırlayıcı Alman hukukunda geçerli olan esasları kendisine dayanak olarak alabileceği, somut olayda (münferit olarak) değerlendirilmelidir. Esas itibariyle usul hukuku kapsamında değerlendirilmesi gereken icrayı sınırlayıcı ulusal esaslar göz önünde bulundurulmalıdır. ${ }^{69}$ Bununla birlikte somut olayda ulusal icra yasaklarının dikkate alınması haksızlığa yol açabilmektedir. ${ }^{70}$ Buna karşın hangi ölçüde bir alacağın haczedilebileceği, alacağın tâbi olduğu hukuka göre belirlenir. ${ }^{71}$

\section{Yabancı Ülkedeki Etkileri}

Başka bir devletin kendi hukuk kuralları çerçevesinde gerçekleştirdiği, varlıkların hukuki statü değişikliklerinin tanınmasının gerekliliği şeklinde bir devletler hukuku yükümlülüğü mevcut değildir. ${ }^{72}$ Buna karşın bir devletin bu şekildeki işlemleri tanıması engellenemez. ${ }^{73} \mathrm{Bu}$ konudaki şartların belirlenmesi esas itibariyle ulusal kanun koyucunun meselesi olmakla birlikte, bu konuda öğretiden ve yarg1 kararlarından yararlanılması mümkündür. ${ }^{74}$ Almanya'da yabanc1 icra işlemlerinin, yabanc1 icra takiplerinin yabancı ülkenin egemenliğine dayanılarak gerçekleştirilmiş olmas ${ }^{75}$ ve yabancı ülkenin müdahalesinin kendi hâkimiyet alanı içerisinde bulunan varlıklarla sınırlı olması halinde tanınması zorunludur. ${ }^{76}$ Böylece

69 Krş. Reichel AcP 1929, 293, 302; Gottwald IPRax 1991, 285, 290.

${ }^{70}$ Krş. LG Oppeln ZZP 19, 470 Cohn’un şerhi ile.

71 Stein/Jonas/Brehm, ZPO, § 829 prg. 105.

72 Rheinstein RabelsZ 8 (1934), 277, 283.

73 Rheinstein RabelsZ 8 (1934), 277, 284.

74 Rheinstein RabelsZ 8 (1934), 277, 285.

75 RGZ 36, 355, 357; RGZ 77, 250, 252; RG Seuff. Arch. 63 Nr. 27; RGZ 132, 128, 129; OLG Oldenburg IPRax 1997, 338, 340; Gottwald IPRax 1991, 285, 288; Schlosser, EUZ/EuGVVO, md. 32 EuGVVO prg. 6; ayrıca krş. BGH NJW 1989, 1351.

76 BVerfGE 64, 1, 19, 20; BAG IPRax 1997, 335, 336. 
örneğin yabancı bir ülkede gerçekleștirilen menkul bir malın açık artırma yoluyla satışı yurtiçinde kabul edilmeyebilir. ${ }^{77}$ Açık artırma yoluyla satış nedeniyle ortaya çıkan mal varlığındaki azalmalar bağlayıcı niteliktedir. Yabancı alacak hacizleri ${ }^{78}$ ve yurtdışında gerçekleştirilen bir Alman limited şirketi [Gesellschaft mit beschränkter Haftung $(\mathrm{GmbH})]^{79}$ bünyesindeki şirket hisselerinin haczi de Almanya da tanınmıştır. ${ }^{80}$ Yurtiçinde ikamet eden borçlunun, yabancı üçüncü kişiden alacaklarının haczi yabancı ülkenin mülkî hâkimiyeti sebebiyle tanınmalıdır. ${ }^{81}$

Örneğin tazminatsız istimlâk niteliğinde olmaları nedeniyle ${ }^{82}$ Alman kamu düzenine (ordre public) aykırılık teşkil eden işlemler veya icra takibi yürütülen ülkenin, işlemi tanıyacak olan ülke açısından bakıldığında yetkisiz olarak yaptığ işlemler $^{83}$ fiili olarak (de facto) tanınmamaktadır. Bu ikinci husus çekişmeli yargı sürecindeki kararlara yönelik kurala uygundur (ZPO md. 328). Hong Kong bu durumu açık bir şekilde, hatta Hong Kong'daki bir alacak meselesi için, kanuni olarak düzenlemiştir. ${ }^{84}$ Almanya'da bu hususlara ek olarak, yabancı bir icra takibinin tanınmasının, bu kararın ilgili yabancı ülkede geçerli olmasını ve sadece bu ülke için söz konusu olmamasını yani ya borçlunun ya da üçüncü kişinin yabancı ülkede ikamet etmesini ya da üçüncü kişinin yurtdışındaki şubesine tebligatta bulunulmuş olmasını gerektireceği savunulmaktadır. ${ }^{85}$ İsviçre' de yabancı icra işlemlerinin genel itibariyle tanınamayacağı şeklinde bir görünüm sergilenmektedir. ${ }^{86}$ Belçika' da durum biraz daha farklılık göstermektedir. ${ }^{87}$ İngiltere'de Lord Goff'un ${ }^{88}$ ifadeleri ancak şu belirtilen hallerde yabanc1 haciz işlemlerinin tanınabileceğine işaret etmektedir: (1) icra takibinin dayanağını oluşturan kararın İngiltere'de tanınması, (2) haczedilen alacağın

77 BGH NJW 1989, 1351.

78 RGZ 36, 355, 357; RG Seuff. Arch. 63 Nr. 27; RGZ 132, 128, 129; OLG Hamburg Niemeyer'sZ 102, 271.

79 OLG Oldenburg IPRax 1997, 338, 340.

80 Dominik Cumhuriyeti'ndeki bir alacağın haczi hakkında krş. BGH RIW 2002, 456 ve OLG Celle IPRspr. 1999 Nr. 31 (olayın tamamı kararda yer almamaktadır).

${ }^{81}$ Schlosser, EUZ/EuGVVO, md. 32 EuGVVO prg. 6; RGZ 36, 355, 357.

${ }^{82}$ Zöller/Geimer, ZPO, § 328 prg. 81a.

${ }^{83}$ krş. BAG IPRax 1997, 335, 337; Gottwald IPRax 1991, 285, 288; ayrıca bkz. Stein/Jonas/ Brehm, ZPO, § 829 prg. 105.

84 krş. Société Eram Shipping Company Ltd. v. Hong Kong and Shanghai Banking Corp. Ltd. [2003] UKHL 30 http://www.publications.parliament.uk/pa/ld200203/ldjudgmt/jd030612/ soci-1.htm.

85 Stein/Jonas/Brehm, ZPO, § 829 prg. 105.

${ }^{86}$ krş. BGE 129 III 683, 687.

${ }^{87}$ krş. Fallon, Le référé international en matière civile et commerciale, Rev. Dr. U.L.B. 1993, 43, 79 ; Born/Fallon/Boxstael, Droit judiciaire international, prg. 244.

${ }^{88}$ Deutsche Schachtbau v. Shell International Petroleum Co. Ltd. [1990] 1 A.C. 295, 354. 
icra takibi yürütülen ülkede bulunması, (3) üçüncü kişi tarafından yapılan ödemelerin uygulanabilir yabancı hukuk uyarınca borçtan kurtarıcı bir etkiye sahip olması. ${ }^{89}$ Yakın bir zaman içerisinde Lordlar Kamarası, üçüncü kişinin, cebri icra alacaklısına yapacağı ödeme ile cebri icra borçlusuna karşı kendi borcundan kurtulacağının kesin olmaması halinde bir alacağın haczinin ve bu nedenle havalesinin kabulünün mümkün olmadığı kararına varmıştır. ${ }^{90}$

Her halükârda en geç cebri icra borçlusu ile üçüncü kişi arasındaki yarg1 sürecinde üçüncü kişinin, cebri icra alacaklısına ödemede bulunduğu yönündeki itirazının ele alınması gerekecektir. Üçüncü kişi itirazını yurt dışında geçerli bir etkiye sahip olan hacze ya da sebepsiz zenginleşmeye dayandırabilir. Borçtan kurtarıcı şekilde bir ödemenin gerçekleşip gerçekleşmediği, sebepsiz zenginleşme itirazında olduğu gibi, haczedilen alacağın tâbi olduğu hukuka göre belirlenir (EGBGB [Einführungsgesetz zum Bürgerlichen Gesetzbuch (Alman Medeni Kanunu`nun Yürürlüğ̈̈ Hakkında Kanun)] md. 32). ${ }^{91}$ Fakat doğru alacakliya ödeme yapılıp yapılmadığ 1 sorusu hâlâ yoruma açık bir konu olarak kalmaktadır ${ }^{92}$ ve alacağın bulunduğu yer ile bir bağlantısı yoktur, çünkü alacağın bulunduğu yer hususu doktrinde hâkim olan görüşe göre ülkesel müdahalenin kabul edilebilirliği ve geçerliliği konusunda belirleyici rol oynamaktadır.

\section{Alacakların Bulunduğu Yer}

Uluslararası alacakların haczinde farazi asıl problem hacizli alacakların bulunduğu yerin tespitinde yatmaktadır. Yukarıda belirtildiği gibi, gerçekleştirilen alacak hacizlerinde bir karara varmayı kolaylaştıran ulusal nitelikte kurallar mevcuttur. ${ }^{93}$ Burada dayanak noktası lex fori (hâkimin hukuku) kurallarıdır. ${ }^{94}$ Buna karşın bu kuralların birbirlerinden farklı olması nedeniyle, uluslararası kararlarda bir uyum söz konusu olamamaktadır. Bazı durumlarda birden çok ülkenin ilgili alacağın kendi hâkimiyeti alanında bulunduğunu kabul etmesi ya da alacağın hiç bir tabiiyetinin bulunmadığının kabul edilmesi söz konusu olabilmektedir. Yani bağlanma noktası olarak ikametgâh net sonuçlara götürememektedir. Üçüncü kişinin ikametgâhının öne çıkması halinde ise bu kişinin birden çok ikametgâhının bulunması durumunda bu kişi tüm malvarlığı açısında ilgili ikametgâhının bulunduğu

\footnotetext{
89 Dicey \& Morris, Conflict of Laws, prg. 24-076; İngiltere'deki hukuki durum için krş. Rheinstein RabelsZ 8 (1934), 277, 299 vd.

90 Société Eram Shipping Company Ltd. v. Hong Kong and Shanghai Banking Corp. Ltd. [2003] UKHL 30, Lord Bingham of Cornhill, prg. 26, http://www.publications.parliament .uk/pa/ld200203/ldjudgmt/jd030612/soci-1.htm.

${ }^{91}$ Looschelders, IPR, md. 38 prg. 15; Palandt/Heldrich, BGB, EGBGB md. 38 prg. 2.

${ }^{92}$ krş. LG Dresden JW 1933, 2350, 2352; Oberstes Tribunal zu Kaunas JW 1927, 2349.

93 krş. BGH MDR 1959, 100, 101; Dicey \& Morris, Conflict of Laws, prg. 22-026; Cuniberti JCP (E) 2003, 664, 665; Mössle, Internationale Forderungspfändung, 31.

${ }^{94}$ krş. RG Seuff. Arch. 63 Nr. 27.
} 
ülkelerin icra erkine tâbidir. ${ }^{95} \mathrm{Bu}$ halde alacağın yerinin belirlenmesi artık bir önem arz etmemektedir. ${ }^{96}$ Fransız içtihatlar1 ${ }^{97}$ ve Alman içtihatlar1 ${ }^{98}$ bu anlayışın kabul edildiği şeklinde bir görünüm sergilemektedir. İngiltere'de bu durum önlenmek istenmektedir ve bu nedenle alternatif olarak ilgili tartışmalı edimin ifa edileceği yer bağlanma noktası olarak kabul edilmesi istenmektedir. ${ }^{99}$ Örneğin kural olarak hesabın bulunduğu şubenin bulunduğu yerde ifa edilmesi gereken banka hesabı bakiyeleri ile ilgili alacaklarda olduğu gibi ${ }^{100}$ borç ilişkisinden, borç ilişkisinin muayyen yeri olarak tanımlanabilecek bir yerin ön plana çıkması halinde, ifa yeri bağlanma noktası olarak ikametgâh unsuru karşısında önceliğe sahip olacaktır. ${ }^{101}$ LuGVÜ'nün ${ }^{102}$ uygulama alanı içerisinde bu durum LuGVÜ md. 16 nr. 5 uyarınca zorunluluk olarak ortaya çıkmaktadır. ${ }^{103}$

Fakat alacaklar biraz fikri, farazi özelliğe sahiptir. ${ }^{104}$ Bundan dolayı bunların bulundukları yer her halükârda farazi niteliğe sahip olabilir. ${ }^{105}$ Alacağın bulunduğu yer tartışması, özellikle alacağın bulunduğu yerin ne Almanya'da (krş. ZPO md. 23 c. 2) ne İsviçre'de ${ }^{106}$ ve ne de Fransa' da ${ }^{107}$ mahkemelerin yetkisini belirleyen bir husus olmaması nedeniyle getirisi olan bir tartışma değildir, ki mahkemelerin yetkisi buralarda daha ziyade kapsamlı bir şekilde kabul görmektedir. ${ }^{108} \mathrm{Bu}$ durumun nasıl keyfi olarak

95 Ayrıca krş. Stein/Jonas/Brehm, ZPO, § 829 prg. 105.

96 krş. Cuniberti JCP (E) 2003, 664, 665.

${ }^{97}$ Cass.civ., 30.01.2002, JCP (E) 2003, 663, 664 Cuniberti 'nin şerhi ile, 664, 665.

98 OLG Hamburg Niemeyer'sZ 1902, 271, 281.

99 Dicey \& Morris, Conflict of Laws, prg. 22-029; Société Eram Shipping Company Ltd. v. Hong Kong and Shanghai Banking Corp. Ltd. [2003] UKHL 30, http://www.publications. parliament.uk/pa/ld200203/ldjudgmt/jd030612/soci-1.htm.

${ }^{100}$ Dicey \& Morris, Conflict of Laws, prg. 22-029; Société Eram Shipping Company Ltd. v. Hong Kong and Shanghai Banking Corp. Ltd. [2003] UKHL 30, Lord Hobhouse of Woodborough, prg. 72, http://www.publications.parliament.uk/pa/ld200203/ldjudgmt/ jd030612/soci-1.htm.

${ }^{101}$ farklı görüşte wohl Cass.civ., 30.01.2002, JCP (E) 2003, 663, 664.

102 ÜBEREINKOMMEN über die gerichtliche Zuständigkeit und die Vollstreckung gerichtlicher Entscheidungen in Zivil- und Handelssachen Geschlossen in Lugano am 16. September 1988 (88/592/EWG), (Özel Hukuk ve Ticaret Hukuku Konularında Yargl Yetkisi ve Yargl Kararlarının Tenfizine Dair 16 Eylül 1988 tarih ve 88/592/AET sayll Lugano Anlașmasl CONVENTION on jurisdiction and the enforcement of judgments in civil and commercial matters Done at Lugano on 16 September 1988 (88/592/EEC)).

${ }^{103}$ Kuwait Oil Tanker Company SAK and others v. UBS AG [2003] UKHL 31 Lord Millett, http://www.publications.parliament.uk/pa/ld200203/ldjudgmt/jd030612/kuwa-1.htm.

104 Mössle, Internationale Forderungspfändung, 31; Schack Rpfleger 1980, 175; krş. Scoles/Hay, Conflict of Laws, § 7.3; Audit, Droit International privé, prg. 759.

${ }^{105}$ Aynı yönde açık bir şekilde BGE 107 III, 147, 150; BGE 63 III, 44.

${ }^{106}$ Krş. BGE 107 III, 147, 150.

${ }^{107}$ Cass.civ., 30.01.2002, JCP (E) 2003, 663, 664.

${ }^{108}$ Ayrıca krş. Schack Rpfleger 1980, 175 vd. 
ele alındığını, yurtiçinde bulunulan yeri yurtiçi yetki hususu ile bağlayan BGB [Bürgerliches Gesetzbuch (Alman Medeni Kanunu)] md. 2369 f. 2 belgelemektedir.

\section{Bağlanma Noktası Olarak Borçlu (Cebri İcra Borçlusu)}

Diğer taraftan, alacakların haczi için hâkimiyet alanı esası mümkün oldukça geniş bir şekilde korunarak, mahkemenin kudretinin kapsama alanının güvenli bir şekilde belirlenebileceği bir kritere ihtiyaç duyulmaktadır. $\mathrm{Bu}$ noktada ilgili alacak üzerinde tasarruf hakkı bulunan borçlunun şahsı ön plana çıkmaktadır, ${ }^{109}$ çünkü haciz ile bu tasarruf yetkisi kendisinden alınmaktadır. ${ }^{110}$ Haciz üçüncü kişiye karşı değil, borçluya karşı etki göstermektedir. ${ }^{111} \mathrm{Bu}$ noktada her haczin asıl mevzuu, -taşınırlardan farklı olarak- lex rei sitae (dava konusu eşyanın bulunduğu yer hukuku) kurallarına değil de özel olarak araştırılıp bulunması gereken sözleşmenin tâbi olduğu hukuka tâbi olan bir alacakta saklıdır. Buna göre alacağın devrinin geçerliliği ve bununla birlikte alacağı devreden asıl alacaklının tasarruf yetkisi EGBGB md. 33 f. 2 uyarınca değerlendirilmelidir. ${ }^{112}$ Buna karşın alacağın bulunduğu yer hakkındaki tartışma ile yapay bir şekilde, -taşınırların haczinden farklı olarak- muhakeme edilmesi gereken müdahalenin karakterine uymayan lex rei sitae (dava konusu eşyanın bulunduğu yer hukuku) kurallarına dayanılmaktadır.

Alacaklar menkullerden farklı olarak değerlendirilmelidir. Bunların mevcudiyeti bir hukuki ilişkiye bağlıdır ve bu ilişkinin yeri bu ilişkiye uygulanacak hukuk yönünden belirleyicidir. Alacaklar, üzerlerinde kısa süreliğine tasarrufta bulunulabilen mal varlığı değerleridir ve mevcudiyetleri kolay bir şekilde dış etkilere maruz kalabilmektedir, çünkü katılımcıların yeri sabit değildir ve alacak ilişkisi kolay bir çözünürlüğe sahiptir. Kim bu çözünürlüğü etkilemek isterse, alacak üzerinde değil de, tasarrufta bulunmaya salâhiyetli kişi üzerinde hukuki güce sahip olmalıdır. Alacağın yeri olarak genel itibariyle, bunun için uygun sorumluluğun dayanağının (üçüncü kişinin serveti) mevcut olduğu yer kabul edilmektedir. ${ }^{113}$ Fakat bu kişinin ikametgâhı, bu kişinin malvarlığının nerede olduğu hususunda değil de, sadece bu kişi hakkında nerede dava açılabileceği hususunda bilgi vermektedir. Burada asıl söz konusu olan müsaderenin konusu değil aksine kendi mal varlığı ile ilişkisi değiştirilecek olan ilgili kişi üzerindeki güçtür. Her bir adli ve idari talimat, alacaklının tasarruf yetkisine müdahale gerektirmektedir ve böylece tasarrufa yetkili kişi üzerinde bir yarg1 erkini gerekli kılmaktadır. Borçlunun haczedilecek alacak üzerindeki tasarruf

109 Aynı yönde OLG Hamburg Niemeyer'sZ 1902, 271, 278 vd. ve Rheinstein RabelsZ 8 (1934), 277, 289; ayrıca krş. Oberstes Tribunal zu Kaunas JW 1927, 2349.

${ }^{110}$ krş. Jestaedt IPRax 2001, 438, 439; Rheinstein RabelsZ 8 (1934), 277, 292.

${ }^{111}$ LG Dresden JW 1933, 1350, 1352.

112 BGH IPRax 1991, 248, 249.

${ }^{113}$ Rheinstein RabelsZ 8 (1934), 277, 293. 
yetkisinin bağlanma noktası olarak kabul edilmesi halinde bu alacak ilgili icra mahkemesinin bulunduğu yerde somutlaştırılmaktadır ve haciz ile duyurulmaktadır. Borçlunun birden çok ikametgâhının bulunması halinde, bu kişi kendisini keyfi olarak kendisinin ikametgâhının bulunduğu diğer devletlerin icra erkine de tâbi kılmaktadır. Buna karşın üçüncü kişinin ikametgâhıyla olan farazi bağlanma, borçlunun malvarlığının kontrol dışı ve üçüncü kişinin ticari olarak faaliyet gösterdiği yere bağlı olan bir müdahaleye maruz kalması sonucuna götürmektedir. Aslında Almanya'da oturan bir borçluya karşı Almanya' da verilen haciz kararı dünya çapında etki göstermelidir; yurtdışında da etkili olacak şekilde alacak üzerindeki tasarruf kudretinin konumunun değiştirilmesinin, mahkeme talimatının üçüncü kişinin yurtdışındaki ikametgâhına tebliği ile ilan edilmesi ve böylece üçüncü kişinin kendisini, alacağın kendisinden ispat gücüne sahip belgelere dayanılarak ikinci defa talep edilme tehlikesine karşı koruyabilecek duruma gelmesi halinde, bu kabul edilebilir. Haczin Alman hukuku açısından üçüncü kişiye tebligatı gerektirmesi (ZPO md. 829 f. 3) dolayısıyla, üçüncü kişinin bilgilendirilmesi teminat altına alınmıştır. ${ }^{114}$ Tebligatın yapılamaması halinde, üçüncü kişi BGB md. 407'ye kıyasen korunur. ${ }^{115}$

Buna karşın alacağın bulunduğu yer esası vasıtasıyla farazi olarak varlığı kabul edilen ülke içerisindeki üçüncü kişi üzerindeki mahkemenin kudreti ile her zaman borçlunun alacak üzerindeki tasarruf kudreti kırılmaz; bu noktada sadece ülke içerisinde üçüncü kişiye, alacağın cebri icra alacaklısına havale edilmesi ödevi yüklenmektedir. Buna karşın borçlunun yurtdışında oturuyor olması halinde alacağın müsaderesi hakkında esas itibariyle bir yargı erki söz konusu değildir. ${ }^{116} \mathrm{Bu}$ durumda kararı tanıyacak olan yabancı devletin, üçüncü kişiye karşı asıl davayı takip eden başka bir davada borçlunun davacı olabilme sıfatının varlığını reddedip edemeyeceği sorusu cevapsız kalmaktadır. Ayrıca bu durumda cebri icra borçlusu icra takibi yürütülen ülkenin yarg1 kuvvetine tâbi olmadığı iddiasında bulunabilir.

Borçlunun tasarruf kudretinin bağlanma noktası olarak alınmasının sonucu olarak, icra erkinin devamlı olarak borçlunun oturduğu yerde ya da ikametgâhının bulunduğu yerde gerçekleştirilebilmesi kabul edilebilir. Bu bakımdan, EuGVVO md. 22 nr. 5 (EuGVÜ md. 16 nr. 5) hükmünün icra hukuku kapsamındaki yabanc1 hâkimiyet alanlarına olan müdahalelerden kaçınma eğiliminde olduğuna ${ }^{117}$ ve EuGVVO md. 3 f. 2 hükmünün esas itibariyle Avrupa Birliği içerisinde ZPO md. 23'de kaynağını bulan tamamlayıcı nitelikteki yetki kurallarına müracaat yolunu kapattığına dikkat

\footnotetext{
${ }^{114}$ Aynı yönde krş. Schack IPRax 1997, 318, 321.

115 Schack IPRax 1997, 318, 321.

${ }^{116}$ Demokratik Almanya Cumhuriyeti'nde müsadere hakkında krş. BGH MDR 1959, 100, 101.

${ }^{117}$ Kropholler, Europäisches Zivilprozessrecht, md. 22 prg. 60.
} 
edilmelidir. ${ }^{118}$ Hatta Lordlar Kamarası biraz daha ileri giderek Denilauler ${ }^{19}$ olay1 1şığı altında LuGVÜ md. 16 nr. 5 hükmünden bir çeşit kendi kendini sınırlayıcı bir prensip çıkarmış, bunun sonucu olarak üye devletlerin, icra takibinin yürütüldüğü ülke içerisinde yer alan eşyalar üzerindeki icra yetkisi sınırlanmıștır. ${ }^{120}$ EuGVVO md. 22 nr. 5 (EuGVÜ md 16 nr. 5)'nün gerçekten icra yetkisini düzenleyip düzenlemediği tartışmalıdır, çünkü bu hüküm sadece, konusu mahkeme kararlarına dayanan cebri icra olan çekişmeli yargıyı düzenlemektedir. ${ }^{121}$

\section{Aynı Alacağın Tekrar Talep Edilmesi İtirazı}

Alacaklara müdahalenin sadece borçlu aracıllğıyla meydana gelmesi halinde, Anglo-Amerikan mahkemelerinin görüşleri uyarınca üçüncü kişiden aynı alacağın hiç bir şekilde ikinci defa talep edilmemesi sağlanmalıdır. Sebepsiz zenginleşme itirazı, ${ }^{122}$ Anglo-Amerikan anlayışı açışından bu konuda geçerli bir itiraz niteliğini haiz değildir. ${ }^{123}$ İngiliz mahkemeleri bu nedenle aynı alacağın (muhtemelen) ikinci defa ödenmesi itirazını henüz icra takibi süreci içerisinde dikkate almaktadırlar. ${ }^{124} \mathrm{ABD}^{\prime} \mathrm{de}$ bu tür mülahazalar yetkinin belirlenmesi kapsamında değerlendirilmektedir. İngiltere'de icra davası katılımcıları, davaya katılacak olan üçüncü kişilerin muhtemel öncelik haklarına işaret etmelidirler (CPR rule 72.8). Mahkeme tarafları dinledikten sonra tarafların hakları üzerinde karar verir. Öncelik esasının ön plana çıkarılıp çıkarılmayacağı mahkemenin takdirine kalmıştır. Genel itibariyle öncelik esası ön plana çıkarılmaktadır. İngiltere'de yabancı icra işlemleri görüldüğü kadarıyla dikkate alınmaktadır. ${ }^{25}$ Alman hukuku açısından bakıldığında icra sürecinde böyle bir itiraz söz konusu değildir. ${ }^{126}$ Aynı alacağın birden fazla haczi geçerlidir (ZPO md. 853). Buna karşın katı bir şekilde uygulanan öncelik esası geçerlidir. ${ }^{127}$ (Yurtdışında dahi) borçluya

\footnotetext{
${ }^{118}$ Jestaedt IPRax 2001, 438, 440; farklı görüşte OLG Saarbrücken IPRax 2001, 456, 457.

${ }^{119}$ EuGH IPRax 1980, 95, 96 prg. 16.

120 Kuwait Oil Tanker Company SAK and others v. UBS AG [2003] UKHL 31, http://www.publications.parliament.uk/pa/ld200203/ldjudgmt/jd030612/kuwa-1.htm.

${ }^{121}$ Kropholler, Europäisches Zivilprozessrecht, § 22 prg. 61; Geimer IPRax 1986, 209.

${ }^{122}$ Ayrıca krş. Rheinstein RabelsZ 8 (1934), 277, 287 vd.

${ }^{123}$ Lord Millett in: Société Eram Shipping Company Ltd. v. Hong Kong and Shanghai Banking Corp. Ltd. [2003] UKHL 30, prg. 109 vd., http://www.publications.parliament.uk/ pa/ld200203/ldjudgmt/jd030612/soci-1.htm.

${ }^{124}$ Martin v Nadel [1906] 2 K.B. 26; Swiss Bank Corp. v. Böhmische Industrial Bank [1923] $1 \mathrm{~KB} 673$.

${ }^{125}$ Dicey \& Morris, Conflict of Laws, prg. 24-076.

${ }^{126}$ krş. RGZ 77, 250, 253; BAG IPRax 1997, 335, 337.

${ }^{127}$ ZPO md. 804 f. 3; ayrıca krş. Gottwald IPRax 1991, 285, 289; devir hakkında BGH IPRax 1991, 248, 249.
} 
ödeme yapılması üçüncü kişiye yasaklanmıştır. ${ }^{128}$ Yabancı ülkede gerçekleştirilen işlemler dikkate alınmaktadır. ${ }^{129}$ İmparatorluk mahkemesi, yurtiçinde verilen öncelikli haciz kararının yurtdışında tanınıp tanınmamasının önemsiz olduğu görüşüne ${ }^{130}$ atıfta bulunmuş, diğer taraftan da Romanya'da öncelikli olarak verilen alacağın haczi kararını esas itibariyle yurtiçinde tanımıştır. ${ }^{131}$ Aynı şekilde İsviçre kaynaklı bir ilamsız haczin işleme konulmasına karar verilmiştir. ${ }^{132}$ Oldenburg yüksek eyalet mahkemesi [Oberlandesgericht Oldenburg (OLG Oldenburg)] ise Hollanda'da verilen limited şirket hissesinin haczi kararını tanımıştır. ${ }^{133}$ Sadece federal iş mahkemesi [Bundesarbeitsgericht $(B A G)$ ] yurtdışında gerçekleştirilen alacak haczinin tanınmasını reddetmiştir. ${ }^{134}$

Code Civil (Fransız Medeni Kanunu) md. 2093 hükmüne rağmen alacakların haczi için söz konusu olan öncelik esası Fransa'da da tanınmaktadır. ${ }^{135}$ Fakat bunun istisnası hacizlerin, "au marc du franc" (orantılı) paylaşımın sonucu olarak aynı gün gerçekleştirilmiş olmasıdır. ${ }^{136}$ Fransa'da göründüğü kadarıyla yabancı icra işlemlerinin tanınması yolu kapatılmış değildir, fakat bunun şartı bu işlemlerin Fransız Devleti'nin hâkimiyet alanına bir müdahale teşkil etmemesidir. Buna karşın yabancı nitelikteki işlem resmi bir tanımaya ihtiyaç duymaktadır, ${ }^{137}$ bu olmaksızın yabancı nitelikli icra işlemi Fransa'da dikkate alınmamakta ve alacaklının tasarruf kudretine müdahale edilememektedir. ${ }^{138}$ Fransa' da oturan üçüncü kişiye karşı haczin tanınması yolu görünüşe göre kapalıdır. ${ }^{139}$ İsviçre' de SchKG [Bundesgesetz vom 11. April 1889 über Schuldbetreibung und Konkurs (11 Nisan 1889 tarihli İsviçre Federal İcra İflas Kanunu)] md. 110, 111 uyarınca gruplama sistemi ile çalışılmaktadır. Gruplamanın başlangıç tarihi kesin haczin gerçekleştirildiği tarihtir. Bunu takip eden günde diğer alacaklılar için söz konusu olan 30 günlük hacze iştirak süresi başlar. Haczedilen malların bedellerinin yeterli olmaması halinde bir sıra cetveli

${ }^{128}$ RGZ 140, 132.

${ }^{129}$ krş. RGZ 132, 128, 130.

${ }^{130}$ RGZ 77, 250, 253.

${ }^{131}$ RGZ 36, 355, 357.

${ }^{132}$ RG Seuff. Arch. 63, Nr. 27.

${ }^{133}$ OLG Oldenburg IPRax 1997, 338.

${ }^{134}$ BAG IPRax 1997, $335 \mathrm{vd}$.

${ }^{135}$ Md. 43 alternatif 2 Kanun Nr. 91-650; TGI Lyon, 22.02.1994, D. 1995, 64; Dalloz Action, Droit et Pratique des voies d'exécution, prg. 4930.

${ }^{136}$ Md. 43 alternatif 3 Kanun Nr. 91-650.

${ }^{137}$ Audit, Droit international privé, prg. 770.

${ }^{138}$ Poitiers, 20.12.1972, RC 1974, 118; belirli iflas etkilerinin doğrudan tanınması hakkında ayrıca krş. Cass.civ., 25.02.1986, RC 1986, 589.

${ }^{139}$ krş. Loussouarn/Bourel, Droit international privé, prg. 448. 
51

düzenlenir (SchKG md. 146 f. 1). Belçika'da ${ }^{140}$ Finlandiya'da, Yunanistan 'da, İtalya'da, Lüksemburg'da ve Hollanda'da benzer bir sistem işlemektedir. $\mathrm{Bu}$ ülkelerde yabancı icrai işlemlerin tanınması söz konusu değildir.

\section{Sonuç}

Uluslararası alacakların haczi, Çekişmesiz Alacaklar Hakkında Avrupa İcra Ilâmının Çıkartılmasına Dair 21 Nisan 2004 tarih ve 805/2004/AT sayll Avrupa Parlementosu ve Konseyi Tüzüğü 'nün 21.10.2005'de yürürlüğe girmesiyle önemi gittikçe artan bir olgudur. Karşılaştırmalı hukuk açısından bakıldığında mahkemeler yabancı ülke unsurunun mevcudiyeti halinde, haczin yurtdışında hangi etkileri göstereceği kesinleştirilemese dahi yetkilerinin varlığını kabul etme yönünde eğilim göstermektedirler. Hâkimiyet esası hakkındaki tartışmalar alacağı, eşya hukuku kapsamına giren bir hak olarak kategorize edilmesi ve alacağın yerinin belirlenmesinin tamamen farazi bir durum olması geniş ölçüde kabul görmesine rağmen alacağın yerinin araştırılması sonucuna götürmektedir. Alacağın haczi, borçlunun tasarruf yetkisi üzerinde etki gösteren kendine has özellikleri haiz bir işlem olması nedeniyle geniş ölçüde kabul görmektedir. Buna karşın şu ana kadar bu anlayış ne açık bir şekilde yetki meselesine ne de tanıma meselesine tesir etmektedir. Karşılaştırmalı hukuk açısından bakıldığında, alacağın haczinin tüm ülkelerde cebri icra işlemi olarak gerçekleştirilemediği maalesef gözlemlenmektedir. $\mathrm{Bu}$ ise öncelik esası açısından, zamansal olarak öncelikli olan haciz işleminin tanınacağı, alacakların haczine yönelik uluslararası bir sistem geliştirilmesine engel olmaktadır. Buna karşın alacakların haczinde alacağın bulunduğu yerin araştırılması isabetli değildir. $\mathrm{Bu}$ noktada söz konusu olan keyfi ve tanımlamalara bağımlı bir metottur. Alacağın haczinin, alacaklının tasarruf yetkisine bağlanmasıyla birlikte, haciz ile sadece tasarruf yetkisi olan kişi üzerinde direk müdahale yetkisi olan bir mahkeme tarafından gerçekleștirilebilecek olan borçlunun alacağının müsaderesinin bağlantılı olduğ ${ }^{141}$ durumu göz önünde bulundurulmaktadır. Buna karşın burada alacağa karşı bir ișlemin söz konusu olduğu doğru değildir ${ }^{142}$, çünkü bu alacak üzerinde bir devlet, ilgili haklar ile en yakın ilişki içerisinde bulunan ve münhasır tasarruf yetkisine sahip kişiye başvurmaksızın, alacağın ilgili mahkemenin bulunduğu yerde vücuda gelmemesi nedeniyle tasarrufta bulunamaz. Alacağın haczinin doğasi itibariyle üçüncü kişinin katılımını gerektirmesi hususu fer'i nitelikte bir

\footnotetext{
${ }^{140}$ krş. md. 8, loi hypothécaire: T'Kint, Sûretés, prg. 84.

${ }^{141} \mathrm{krş}$. Lord Millett in: Société Eram Shipping Company Ltd. v. Hong Kong and Shanghai Banking Corp. Ltd. [2003] UKHL 30, prg. 88, http://www.publications .parliament.uk/pa/ld200203/ldjudgmt/jd030612/soci-1.htm.

${ }^{142}$ Lord Millett in: Société Eram Shipping Company Ltd. v. Hong Kong and Shanghai Banking Corp. Ltd. [2003] UKHL 30, prg. 88: it ... takes effect as an order in rem against the debt owed by the third party, http://www.publications.parliament.uk/pa/ld200203/ldjudgmt/jd030612/soci-1.htm.
} 
anlam ifade etmektedir. Üçüncü kişinin muhafazası, alacağın bulunduğu yerin araştırılması haricindeki bir yöntemle sağlanmalıdır.

Burada ön plana çıkarılan uluslararası alacakların haczinin borçlunun tasarruf yetkisi ile bağlanmasının zorunlu bir gereği olarak mahkemelerin uluslararası yetkililiklerinin belirlenmesi söz konusu değildir. Devletler kendi icra yetkilerini bağımsız bir şekilde belirlemekte serbesttirler. Borçlunun tasarruf yetkisine yönelik olarak önerilen bağlanma noktası, devamlı gelişim içerisinde olan küreselleşme süreci içerisinde, etkili bir şekilde sınır aşırı alacakların haczedilebilmesi hususunda engelleyici bir nitelik arz eden ve (bu nedenle) mantıksız gözüken alacağın bulunduğu yer hakkındaki tartışmayı fuzuli hale getirmektedir. Sonuç itibariyle alacaklar, burada bahsedilen anlayışa göre hiç bir sınırlı ülkesel güce değil, aksine kendisi üzerinde tasarruf yetkisine sahip olan güce tâbidir. Borçlunun, yurtdışında oturan üçüncü kişiden tekrar alacağını istemek suretiyle kendisine karşı söz konusu olan mahkeme kararlarına riayet etmemesi hali, iç hukuk açısından kabul edilmesi gereken, (daha doğru bir ifadeyle katlanılması gereken) bir durum teşkil etmektedir. Bu aşamada aynı alacağın ikinci defa talep edilmesine karşı korumayı tesis etmek yabancı hukuk düzeninin görevidir. ${ }^{143}$ Almanya'da, yurtdışında gerçekleştirilen haciz nedeniyle davacı olma sıfatının eksikliği itirazı kabul görmelidir. ${ }^{144} \mathrm{Bu}$ anlayış üçüncü kişinin yurtiçinde oturuyor olması halinde dahi geçerlidir. ${ }^{145}$ Fakat bunun şartı yabancı ülkenin borçlu üzerinde yargılama gücüne sahip olmasidır. ${ }^{146}$

\footnotetext{
${ }^{143}$ krș. OLG Breslau JW 1885, 261, 263.

${ }^{144}$ RG Seuff. Arch. 63 Nr. 27.

${ }^{145}$ OLG Hamburg Niemeyer'sZ 1902, 271, 281.

${ }^{146}$ OLG Hamburg Niemeyer'sZ 1902, 271, 278 vd.; ayrıca krş. Schack Rpfleger 1980, 175, 178; katılmadığımız görüş: Welter, Zwangsvollstreckung und Arrest in Forderungen, 67.
} 
KONFERANS 
